ISSN 0853-8557

\title{
PENGARUH BANTALAN KARET TERHADAP MOMEN YANG TERJADI PADA LINK SLAB BETON
}

\author{
Andi Rahmat ${ }^{1}$, Andreas Triwiyono ${ }^{2}$, Muslikh ${ }^{3}$ \\ ${ }^{1}$ Department of Civil and Environmental Engineering, Universitas Gadjah Mada, INDONESIA \\ Email: andirahmat1990@yahoo.com \\ ${ }^{2}$ Department of Civil and Environmental Engineering, Universitas Gadjah Mada, INDONESIA \\ Email: andreas.triwiyono@ugm.ac.id \\ ${ }^{3}$ Department of Civil and Environmental Engineering, Universitas Gadjah Mada, INDONESIA \\ Email: muslikhjtsl@ugm.ac.id
}

\begin{abstract}
The link slab concrete connecting two span girders which is used as a substitute of expansion joints has been designed as a continuous part of the deck slab and the bottom surface of link debonded to the top surfaces of end girders. In practical retrofitting and replacement of expansion joints are found that the top surfaces of end girders are attached to the rubber pads before cast-in-place of the link slab. Hence there are purely as a tie between the link slab to the rubber pads and the rubber pads to the top surfaces of girders. Therefore this condition needs to be studied by numerical simulation in order to obtain the effect of rubber pads instalation to moments of link slab concrete. Analysis is conducted using Abaqus. Girders, deck slabs, steel bearing, hard rubber pads, and soft rubber pads are modeled as solid 3D. Traffic loads based on SNI 1725:2016 Loads for bridges are applied on the structural system of the link slab concrete. The results show that the installation of the hard rubber pads under the link slab can reduce the magnitude of moments compared to the link slab without rubber pads. This is indicated by the percentage reduction moments between 39,20-83,42\% on LS-1, LS-2, and LS-3 hard rubber pads with thichness $10 \mathrm{~mm}, 20 \mathrm{~mm}$ and $30 \mathrm{~mm}$. While on the link slab with the soft rubber pads is found that moments are greater at the very thick pads This is indicated by the percentage difference in moments between 198,26 - 244,58\% on LS-1,LS-2, and LS-3 soft rubber pads with thickness $10 \mathrm{~mm}, 20 \mathrm{~mm}$ and $30 \mathrm{~mm}$.
\end{abstract}

Keywords: link slab, 3D-solid, moment, hard rubber pads and soft rubber pads

\section{PENDAHULUAN}

Permasalahan yang muncul pada jembatan yang mempunyai lebih dari bentang yang menggunakan expansion joint adalah seiring berjalannya waktu maka expansion joint tersebut akan mengalami kelelahan dan penurunan kekuatan yang berakhir dengan terjadinya retak. Pada saat terjadi retak maka akan terbentuk celah kecil yang akan mengakibatkan air hujan masuk ke dalam celah tersebut. Hal ini akan mengakibatkan korosi pada balok dan perletakan jembatan. Permasalahan yang ada ini akan memberikan ketidaknyamanan bagi pengguna jalan dan dapat mengakibatkan kegagalan struktur bila dibiarkan terjadi korosi terus menerus. Untuk menyelesaikan masalah tersebut maka penggunaan link slab dapat menjadi suatu alternative penyelesaian masalah yang timbul akibat kerusakan pada expansion joint (Sugiharjdo dkk, 2010).

Hong, Yu (2014) menyatakan sistem link slab dapat memberikan manfaat pada pelat lantai jembatan menerus, penyempurnaan desain dan detail dari link slab itu sendiri diperlukan untuk mengoptimalkan jembatan ini sistem dek dan memastikan jangka panjang kinerja. Bahan dengan kapasitas 
regangan tarik tinggi, seperti beton serat (FRC), dapat digunakan untuk aplikasi di link slab untuk meningkatkan kekuatan, daya tahan dan karakteristik retak link slab.

Qian dkk (2009) menyajikan pendekatan inovatif untuk merancang transisi zona antara segmen pelat lantai beton dan link slab dengan bahan engineered cementitious composite yang mudah terdeformasi dan berdampingan dengan pelat lantai jembatan komposit girder baja. Pusat link slab yang semua konektor geser antara gelagar dan geladak dilepas untuk mencegah aksi komposit antara gelagar dan pelat lantai (Gambar 1). Bersamaan dengan pelepasan shear connectors, mekanisme debonding mekanis didapatkan pada top flange gelagar untuk selanjutnya mencegah transfer geser antara gelagar dan pelat lantai. Mekanisme debonding ini dapat berupa standar roofing tar paper (untuk digunakan dengan balok baja) atau plastic sheeting (untuk digunakan dengan balok beton pracetak).

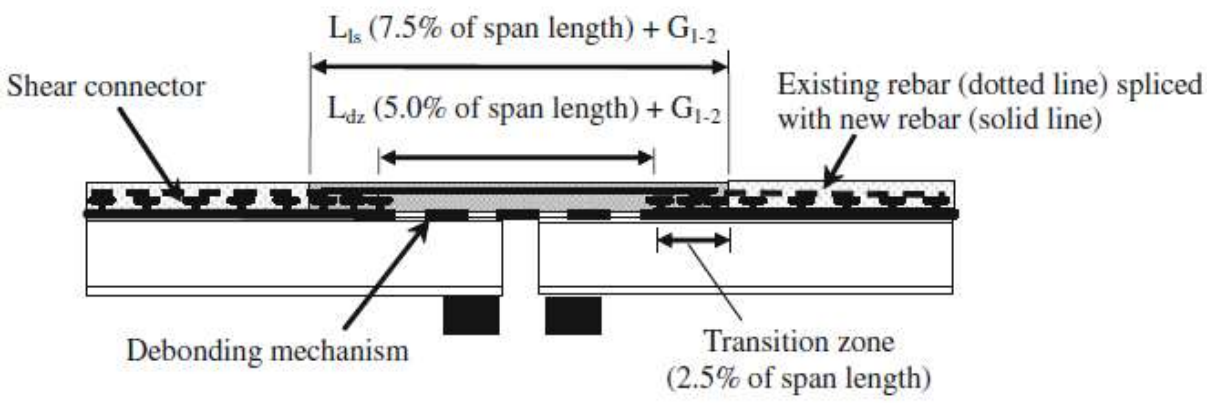

Gambar 1. Skema ECC Link Slab

Sementara aksi komposit dipertahankan pada bentang yang berdekatan, debonding dalam link slab ini memungkinkannya berfungsi lebih efisien sebagai engsel antara dua bentang yang berdekatan saat mereka membelokkan (Gambar 2).

Sugihardjo (2009) memodelkan link slab dengan cara elemen hingga $3 D$ solid dan elemen portal pada jembatan beton prategang bentang $22,25,31,34$, dan 40 meter dengan bantuan software SAP 2000. Bahan yang di gunakan adalah beton normal. Dari hasil analisis numerik disimpulkan bahwa ketebalan link slab minimal $200 \mathrm{~mm}$, ijin tulangan kurang dari $0.4 \sigma_{\mathrm{y}}$. Zona debonding pada penelitian ini ditunjukkan pada Gambar 2.

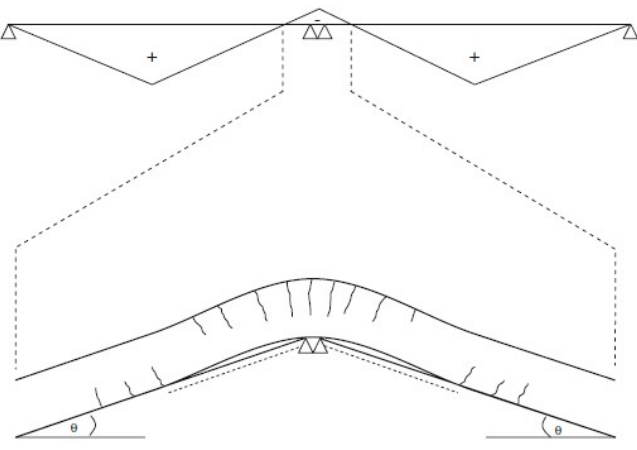

Gambar 2. Distribusi momen bentang jembatan dan mekanisme hinging link slab, Qian dkk (2009) 


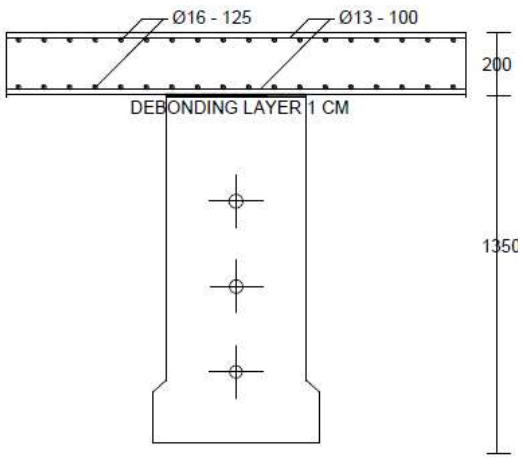

Gambar 3. Penampang tipikal dan penulangan link slab (bentang jembatan 22

m), Sugihardjo dan Supani (2009)

Pada penelitian yang lain, dengan metode analisis numerik menggunakan SAP2000 pada Sugihardjo dkk (2010) mendapatkan zona nirlekat (zona debonding) berkisar antara 5,5 - 14,5\% pada penggunaan link slab dengan bahan beton normal pada jembatan komposit dengan bentang 12, 16, 20, 25 dan $30 \mathrm{~m}$. Zona nirlekat ini ditunjukkan pada Gambar 4.

Menurut Mothe (2006) peningkatan rasio panjang nirlekat menjadikan momen lokal pada link slab menurun. Kondisi ini dapat terjadi karena fakta bahwa link slab pendek lebih kaku pada lentur dan karenanya mereka menghasilkan lebih banyak kesinambungan dalam sistem yang mengarah ke momen terbesar dalam slab.

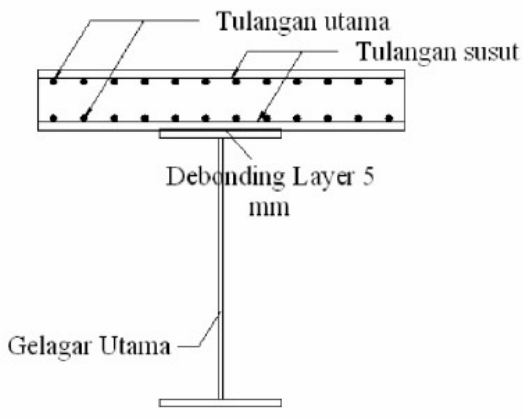

Gambar 4. Posisi debonding layer, Sugihardjo dkk (2010)

Pada beberapa pekerjaan retrofitting jembatan di Indonesia ditemukan peng- gunaan bantalan berbahan karet untuk mengantikan standar roofing tar paper dan plastic sheeting pada zona debonding menurut Qian dkk (2009). Penggunaan bantalan ini memungkinkan terjadi aksi komposit antara link slab, bantalan karet dan gelagar jembatan. Oleh karena itu perlu dilakukan penelitian dengan pendekatan numerik dengan bantuan software ABAQUS untuk mendapatkan informasi penting pengaruh bantalan karet terhadap momen yang terjadi pada link slab.

\section{METODE PENELITIAN}

Analisis numerik link slab berupa pemodelan elemen hingga dengan bantuan software ABAQUS v.6.14-3. Pembebanan berupa beban lalu lintas pada dua bentang gelagar seperti ditunjukkan pada Gambar 8 .

Link slab dimodelkan sebagai pelat menerus dari pelat lantai jembatan yang ditempatkan pada permukaan atas ujung gelagar yang berdekatan seperti pada Gambar 5 dan Gambar 6. Gelagar dan link slab menjadi suatu sistem model yang pada area ujung permukaan bawah gelagar diletakkan di atas bearing baja dengan perletakan sederhana, rol-sendi-sendi-rol.

Metode elemen hingga (finite element analysis) merupakan metode numerik yang menggunakan sistem diskretisasi elemen. Sistem diskretisasi mensyaratkan pembagian elemen-elemen menjadi komponen yang kecil. Pembagian elemen (meshing) dilakukan dengan pada ukuran yang berbeda-beda. Semakin banyak jumlah elemen akurasi pemodelan semakin baik. Kontrol akurasi pemodelan ini disebut konvergensi.

\section{Data Perencanaan}

\section{Data Gelagar Beton Prategang}

Dimensi gelagar beton prategang dalam penelitian ini dapat dilihat pada Gambar 5 dan Gambar 6. Gelagar yang dimodelkan terdiri atas 2 gelagar dengan ukuran yang 
sama yaitu panjang $30,6 \mathrm{~m}$ dan tinggi 1,7 m. Data ini merupakan profil WIKA PCI girder. (Victorianto, 2018).

Material yang digunakan untuk gelagar adalah beton $f_{c}$ ' $40 \mathrm{MPa}$ (Victorianto, 2018). Modulus elastisitas beton ditentukan dengan rumus $\mathrm{w}^{1,5} 0,043 \sqrt{ } \mathrm{f}_{\mathrm{c}}$ ' (SNI 2847 2013) sehingga $E_{c}$ gelagar adalah 35019 MPa. Rasio poisson untuk beton adalah 0,2 (Gere dan Timoschenko, 1990).

\section{Data Link Slab}

Dimensi link slab ditunjukkan pada Gambar 5 dan Gambar 6. Panjang link slab adalah 4,79 $\mathrm{m}$ diperoleh dari 0,075. $\left(L_{s p 1}+L_{s p 2}\right)+\mathrm{GAP} \quad(\mathrm{Li} \quad \mathrm{dkk}, \quad 2003)$. Tebal link slab adalah $0,25 \mathrm{~m}$ mengikuti tebal pelat lantai jembatan profil komposit WIKA PCI girder (Victorianto, 2018). Lebar link slab adalah 1,2 m merujuk pada penelitian yang dilakukan oleh Sugihardjo dkk (2010). Nilai GAP diasumsikan 0,2 m.

Material Link slab adalah beton $\mathrm{f}_{\mathrm{c}}$ ' $25 \mathrm{MPa}$, $30 \mathrm{MPa}$ dan $35 \mathrm{MPa}$ yang didesain menggunakan beton normal sehingga modulus elastisitas ditentukan dengan $E_{c}$ sebesar $4700 \sqrt{\mathrm{f}_{\mathrm{c}}}{ }^{\prime} \quad$ (SNI 2847-2013) sehingga berturut-untuk untuk $E_{c}$ beton $\mathrm{f}_{\mathrm{c}}$, $25 \mathrm{MPa}, 30 \mathrm{MPa}$, dan $35 \mathrm{MPa}$ adalah $23500 \mathrm{MPa}, 25743 \mathrm{MPa}$ dan $27805 \mathrm{MPa}$. Rasio poisson untuk beton adalah 0,2 (Gere dan Timoschenko, 1990).

\section{Data Pelat Lantai}

Dimensi pelat lantai jembatan ditunjukkan pada Gambar 4 dan Gambar 5. Panjang pelat lantai pada 1 bentang gelagar adalah 28,3 m. Diperoleh dari panjang gelagar ( $L_{s p 1}-(0,5 \times$ panjang link slab $+0,5 \times$ GAP $)$.

Material pelat lantai jembatan adalah beton $\mathrm{f}_{\mathrm{c}}{ }^{\prime} 25 \mathrm{MPa}$ (Victorianto, 2018) yang didesain menggunakan beton normal sehingga modulus elastisitas ditentukan dengan $E_{c}$ sebesar $4700 \sqrt{ } \mathrm{fc}$ ' (SNI 28472013) yaitu $23500 \mathrm{MPa}$. Rasio poisson untuk beton adalah 0,2 (Gere dan Timoschenko, 1990).

\section{Data Bantalan Karet}

Bantalan karet terdiri dari 3 jenis geometrik dimana penampang bantalan memiliki luas yang sama, $229,5 \mathrm{~cm} \times 60 \mathrm{~cm}$ dengan masing-masing ketebalan $1 \mathrm{~cm}, 2 \mathrm{~cm}$ dan 3 $\mathrm{cm}$. Panjang bantalan karet $229,5 \mathrm{~cm}$ diperoleh dari 0,5 panjang link slab dikurangi dengan 0,5 GAP. Lebar bantalan karet diperoleh dari lebar top flange gelagar.

Material karet yang digunakan dalam penelitian ini terdiri dari 2 jenis yaitu hard rubber dan soft rubber. Modulus elastisitas hard rubber adalah 2,3 x $10^{9}$ $\mathrm{Pa}$ dan soft rubber adalah $0,005 \times 10^{9}$ $\mathrm{Pa}$ (Karnopp, dkk. 2012 Seymour dan Raymond (1990) menyatakan

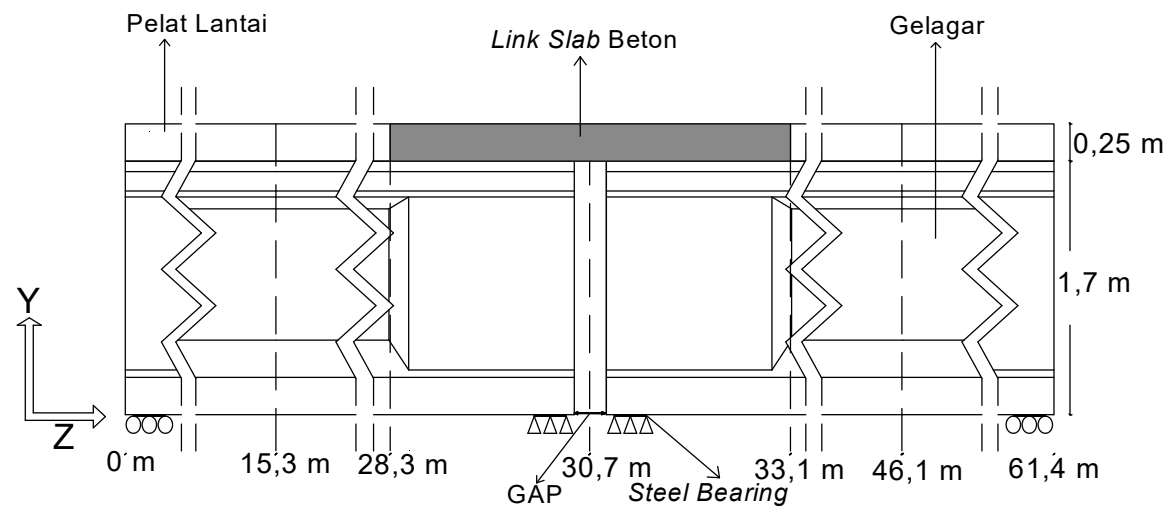

Gambar 5. Skema Link Slab beton tanpa bantalan karet 


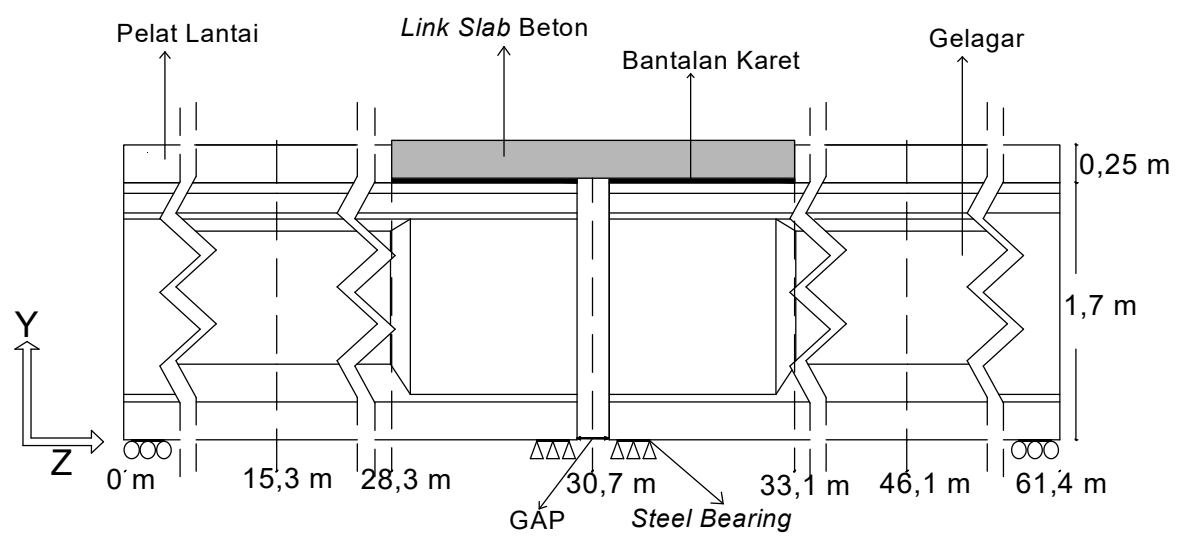

Gambar 6. Skema Link Slab beton dengan bantalan karet

poisson ratio ideal untuk elastomer adalah 0,5 dan polimer gelas sekitar 0,33 . Dalam penelitian ini poisson ratio untuk bantalan karet dipakai 0,4 karena software Abaqus tidak bisa memproses analisis jika menggunakan poisson ratio ideal untuk bantalan karet.

\section{Data Steel Bearing}

Letak steel bearing pada struktur pemodelan ditunjukkan pada Gambar 3 dan Gambar 4. Diasumsikan panjang $=0,4 \mathrm{~m}$, lebar $=0,4 \mathrm{~m}$, dan tebal $=0,01 \mathrm{~m}$.

Material steel bearing adalah baja jenis metals-52100 bearing steel dengan modulus elastisitas $(E)=210000 \mathrm{MPa}$ (Cotell dkk, 1994). . Rasio poisson untuk baja adalah 0,3 (Gere dan Timoschenko, 1990)

\section{Parameter Pemodelan Elemen Struktur}

Parameter pemodelan elemen struktur pada ABAQUS dalam penelitian ini menggunakan model elemen $3 D$ solid linear untuk seluruh komponen.

Gambar tampak 2D pemodelan struktur yang dimodelkan pada ABAQUS v.6.14 dapat ditunjukkan pada Gambar 5 dan Gambar 6. Gambar 5 adalah tampilan 2D dari komponen-komponen struktur desain link slab beton tanpa bantalan karet.
Gambar 6 adalah tampilan 2D dari komponen-komponen link slab beton dengan bantalan karet.

\section{Variasi Pemodelan Link Slab}

Dari detail pemodelan link slab berdasarkan geometri dan sifat bahan maka ditentukan variasi pemodelan dari kombinasi pemodelan link slab tanpa dan dengan bantalan karet seperti pada Tabel 1 .

Link slab beton merupakan variable tetap dalam penelitian ini yang dibagi menjadi 3 jenis berdasarkan kuat tekannya $\left(f_{\mathrm{c}}{ }^{\prime}\right)$ yaitu 25, 30 dan $35 \mathrm{MPa}$.

Link slab beton $\mathrm{f}_{\mathrm{c}}{ }^{\prime}=25 \mathrm{MPa}$ disimbolkan dengan $L S-1$. Link slab beton $\mathrm{f}_{\mathrm{c}}{ }^{\prime}=30 \mathrm{MPa}$ disimbolkan dengan $L S$-2. Link slab beton $\mathrm{f}_{\mathrm{c}}{ }^{\prime}=35 \mathrm{MPa}$ disimbolkan dengan $L S-3$.

Bantalan hard rubber dan soft rubber merupakan variabel tidak tetap yang divariasikan berdasarkan ketebalan yaitu ketebalan $1 \mathrm{~cm}, 2 \mathrm{~cm}$ dan $3 \mathrm{~cm}$.

\section{Identifikasi Model Elemen Hingga Struktur}

Analisis numerik dengan metode elemen hingga adalah solusi pendekatan dengan membagi komponen struktur desain menjadi bagian-bagian kecil (meshing) dalam jumlah tertentu. Dengan metode ini akurasi solusi meningkat seiring dengan 
peningkatan jumlah elemen. Proses ini lebih dikenal sebagai proses konvergensi. Untuk mendapatkan hubungan konvergensi ini sistem link slab dibebani pada bagian tengah link slab seperti pada Gambar 7, pada beberapa jenis ukuran mesh.

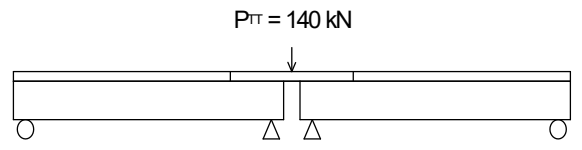

Gambar 7. Pembebanan tengah bentang link slab

Tabel 1. Variasi pemodelan desain link slab

\begin{tabular}{|c|l|l|}
\hline No & Nama & \multicolumn{1}{|c|}{ Keterangan } \\
\hline 1 & M1001 & LS1-tanpa bantalan karet \\
\hline 2 & M1002 & LS2-tanpa bantalan karet \\
\hline 3 & M1003 & LS3-tanpa bantalan karet \\
\hline 4 & M1111 & LS1-bantalan hard rubber $1 \mathrm{~cm}$ \\
\hline 5 & M1121 & LS1-bantalan hard rubber $2 \mathrm{~cm}$ \\
\hline 6 & M1131 & LS1-bantalan hard rubber $3 \mathrm{~cm}$ \\
\hline 7 & $\mathrm{M} 1112$ & LS2-bantalan hard rubber $1 \mathrm{~cm}$ \\
\hline 8 & $\mathrm{M} 1122$ & LS2-bantalan hard rubber $2 \mathrm{~cm}$ \\
\hline 9 & $\mathrm{M} 1132$ & LS2-bantalan hard rubber $3 \mathrm{~cm}$ \\
\hline 7 & $\mathrm{M} 1113$ & LS3-bantalan hard rubber $1 \mathrm{~cm}$ \\
\hline 8 & $\mathrm{M} 1123$ & LS3-bantalan hard rubber $2 \mathrm{~cm}$ \\
\hline 9 & $\mathrm{M} 1133$ & LS3-bantalan hard rubber $3 \mathrm{~cm}$ \\
\hline 10 & $\mathrm{M} 1211$ & LS1-bantalan hard rubber $1 \mathrm{~cm}$ \\
\hline 11 & $\mathrm{M} 1221$ & LS1-bantalan hard rubber $2 \mathrm{~cm}$ \\
\hline 12 & $\mathrm{M} 1231$ & LS1-bantalan hard rubber $3 \mathrm{~cm}$ \\
\hline 13 & $\mathrm{M} 1212$ & LS2-bantalan hard rubber $1 \mathrm{~cm}$ \\
\hline 14 & $\mathrm{M} 1222$ & LS2-bantalan hard rubber $2 \mathrm{~cm}$ \\
\hline 15 & $\mathrm{M} 1232$ & LS2-bantalan hard rubber $3 \mathrm{~cm}$ \\
\hline 16 & $\mathrm{M} 1213$ & LS3-bantalan hard rubber $1 \mathrm{~cm}$ \\
\hline 17 & $\mathrm{M} 1223$ & LS3-bantalan hard rubber $2 \mathrm{~cm}$ \\
\hline 18 & $\mathrm{M} 1233$ & LS3-bantalan hard rubber $3 \mathrm{~cm}$ \\
\hline
\end{tabular}

Hasil dari konvergensi berupa ukuran pembagian elemen sehingga didapatkan jumlah elemen untuk pada masing-masing jenis pemodelan.

\section{Skema Pembebanan Link Slab}

Skema pembebanan pada link slab ditunjukan pada Gambar 8 berikut ini.

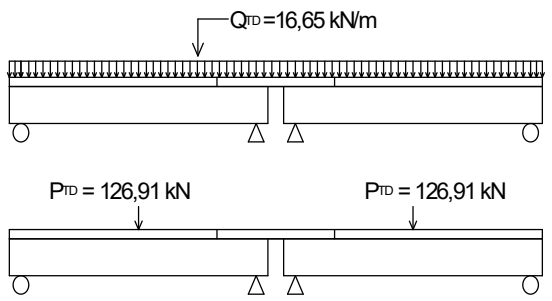

Gambar 8. Skema pembebanan pada link slab akibat beban lalu lintas pada dua bentang gelagar PCI girder

\section{HASIL DAN PEMBAHASAN}

1. Konvergensi Pemodelan Struktur

Dari variasi jumlah elemen didapatkan displacement seperti yang ditunjukkan pada Tabel 2. Dari Tabel 2 diperoleh grafik hubungan antara jumlah elemen dengan displacement seperti yang ditunjukkan pada Gambar 9. Dari Gambar 9 dan Tabel 2 ditunjukkan bahwa perubahan ukuran mesh menjadi lebih kecil membuat jumlah elemen $(n)$ menjadi semakin banyak dan displacement berangsur-angsur mendekati nilai konstan pada ukuran mesh $0,06 \mathrm{~m}$ dengan persentase kesalahan sebesar $-1,4 \%$.

Tabel 2. Displacement pada 1 titik permukaan bawah link slab akibat pembebanan $\mathrm{P}_{\mathrm{TT}}$

\begin{tabular}{|c|c|c|c|}
\hline $\begin{array}{c}\text { Ukuran } \\
\text { mesh }(\mathrm{m})\end{array}$ & $\begin{array}{c}\text { Jumlah } \\
\text { elemen }(n)\end{array}$ & $\begin{array}{c}\text { displacement } \\
(\Delta)(\mathrm{mm})\end{array}$ & $\begin{array}{c}\% \\
\text { kesalahan }\end{array}$ \\
\hline 0 & 0 & 0 & - \\
\hline 0.1 & 96760 & 0.01721 & 100.00 \\
\hline 0.09 & 113434 & 0.01738 & 0.96 \\
\hline 0.08 & 180739 & 0.01657 & -4.91 \\
\hline 0.07 & 261172 & 0.01708 & 3.01 \\
\hline 0.06 & 400376 & 0.01685 & -1.40 \\
\hline 0.05 & 699496 & 0.01680 & -0.27 \\
\hline 0.04 & 1405370 & 0.01676 & -0.26 \\
\hline
\end{tabular}

Ukuran mesh yang digunakan untuk variasi pemodelan link slab dipilih $0,05 \mathrm{~m}$ dengan 
jumlah elemen 699496. Persentase kesalahan ukuran mesh ini adalah $-0,27 \%$.

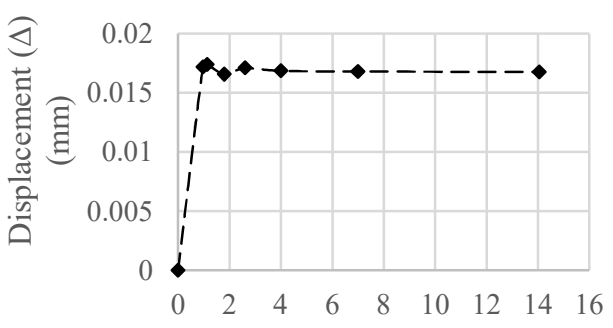

Jumlah Elemen (n/100000)

Gambar 9. Grafik hubungan antara jumlah elemen meshing dengan displacement

2. Tinjauan Momen Pada Variasi Pemodelan Link Slab

Dalam pemodelan ini, pengaruh beban mati dan gaya prategang gelagar $P C I$ diabaikan dengan alasan pada saat dilakukan pengecoran link slab, beban mati gelagar telah bekerja. Salah satu hasil pembacaan momen pada link slab akibat mekanisme pembebanan lalu lintas (Gambar 8) ditunjukkan pada Gambar 10.

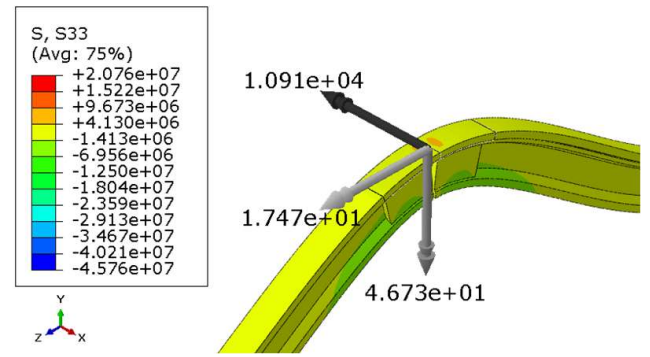

Gambar 10. Momen yang terjadi pada Link Slab di antara dua bentang girder jembatan.

Gambar 10 merupakan model link slab tanpa bantalan karet M1001. Momen yang digunakan untuk pengolahan data adalah momen tengah bentang arah $\mathrm{x}$. Hasil momen M1001 dari pemodelan dalam satuan N.m yaitu $10910 \mathrm{~N}$ atau 10,91 kN.m. Momen pemodelan link slab tanpa dan dengan bantalan karet seluruhnya ditinjau pada tengah bentang link slab.
3. Perbandingan Reduksi Momen Link Slab Tanpa dan Dengan Bantalan Karet

a. Reduksi Momen Pada $L S-1$

1) LS-1 bantalan hard rubber $10 \mathrm{~mm}$

Pada $L S-1$ hard rubber $10 \mathrm{~mm}$ mampu mereduksi momen negatif $L S$-1 tanpa karet sebesar $39.20 \%$. Adapun momen tereduksi termasuk momen negatif. Untuk $L S-1$ bantalan hard rubber $20 \mathrm{~mm}$ mereduksi momen sebesar 57,47 \% dan LS-3 bantalan hard rubber $30 \mathrm{~mm}$ dapat mereduksi momen sebesar $69,59 \%$. Persentase reduksi momen ini dapat dilihat pada Tabel 3.

Tabel 3. Persentase reduksi momen pada $L S$ 1-hard rubber

\begin{tabular}{|c|c|c|c|c|}
\hline Tebal & $\mathrm{M}_{0}$ & $\mathrm{M}_{1}$ & $\begin{array}{c}\text { Selisih } \\
\mathrm{M}_{0}-\mathrm{M}_{1} \\
\text { kN.m }\end{array}$ & $\left(\frac{\mathrm{M}_{0}-\mathrm{M}_{1}}{\mathrm{M}_{0}}\right) \times 100$ \\
$\%$ & kN.m & kN.m & kN.m \\
\hline 10 & $-10,9$ & $-6,627$ & $-4,273$ & 39,20 \\
\hline 20 & $-10,9$ & $-4,636$ & $-6,264$ & 57,47 \\
\hline 30 & $-10,9$ & $-3,315$ & $-7,585$ & 69,59 \\
\hline
\end{tabular}

Dari Tabel 3, $\mathrm{M}_{0}$ adalah momen yang terjadi akibat beban lalu lintas pada link slab tanpa bantalan karet sedangkan $\mathrm{M}_{1}$ adalah momen yang terjadi pada link slab setelah penambahan bantalan karet hard rubber pada zona transisi link slab dengan gelagar beton prategang. Kemudian dari hasil perhitungan persentase pada Tabel 3 diperoleh hubungan antara tebal bantalan karet hard rubber dengan perubahan momen yang terjadi seperti grafik pada Gambar 11.

Pada Gambar 11, dapat dilihat bahwa semakin tebal karet hard rubber semakin besar reduksi momen yang terjadi. Reduksi momen yang terkecil terjadi pada $L S-1$ bantalan hard rubber sebesar 39,2 \% sedangkan reduksi momen yang terbesar adalah pada $L S-1$ bantalan hard rubber 30 mm sebesar 69,59\%.

2) $L S-1$ bantalan soft rubber

Pada $L S$ bantalan soft rubber $10 \mathrm{~mm}$, momen yang terjadi setelah pembebanan memiliki selisih sebesar 205,87\%. Dengan menganggap terbaliknya momen negatif 
menjadi momen positif dengan selisih 200 $\%$ maka momen awal tidak mengalami perubahan besar momen jika dibandingkan dengan perubahan momen. Oleh karena perubahan momen yang terjadi sebesar 205,87 maka dengan mengurangi persentase ini dengan $200 \%$ diperoleh 5,87 $\%$ sebagai tambahan momen yang terjadi. Angka 5,87\% ini juga dapat diperoleh dengan mengabaikan jenis momen negatif atau positif sehingga selisih dapat diperoleh dan didapatkan presentase tambahan $5,87 \%$. Perhitungan persentasi ini dapat di lihat pada Tabel 4.

Tabel 4. Persentase perubahan momen pada $L S 1$ - bantalan soft rubber

\begin{tabular}{|c|c|c|c|c|}
\hline Tebal & $\mathrm{M}_{0}$ & $\mathrm{M}_{1}$ & $\begin{array}{c}\text { Selisih } \\
\mathrm{M}_{0}-\mathrm{M}_{1}\end{array}$ & $\left(\frac{\mathrm{M}_{0}-\mathrm{M}_{1}}{\mathrm{M}_{0}}\right) \times 100$ \\
$(\mathrm{~mm})$ & kN.m & kN.m & kN.m & $\%$ \\
\hline 10 & $-10,9$ & 11,54 & $-22,44$ & 205,87 \\
\hline 20 & $-10,9$ & 11,38 & $-22,28$ & 204,40 \\
\hline 30 & $-10,9$ & 10,71 & $-21,61$ & 198,26 \\
\hline
\end{tabular}

Dari Tabel 4, $\mathrm{M}_{0}$ adalah momen yang terjadi akibat beban lalu lintas pada link slab tanpa bantalan karet sedangkan $\mathrm{M}_{1}$ adalah momen yang terjadi pada link slab setelah penambahan bantalan karet soft rubber pada zona transisi link slab dengan gelagar beton prategang. Kemudian dari hasil perhitungan persentase pada Tabel 5 diperoleh hubungan antara tebal bantalan karet soft rubber dengan perubahan momen yang terjadi seperti grafik pada Gambar 12 .

Dari Gambar 12, dapat dilihat bahwa semakin tebal karet soft rubber semakin besar kemungkinan reduksi momen yang akan terjadi. Reduksi momen link slab bantalan karet soft rubber terjadi pada kondisi $\Delta \mathrm{M}<200 \%$. Dari Gambar 9 dapat dilihat bahwa bantalan karet soft rubber dengan $\Delta \mathrm{M}$ di bawah $200 \%$ adalah bantalan karet tebal $30 \mathrm{~mm}$ sebesar 198,26 \%. Dengan mengabaikan jenis momen positif atau negatif diperoleh reduksi momen yang kecil yaitu $1,74 \%$. b. Reduksi Momen pada $L S-2$

1) LS-2 bantalan hard rubber

Pada LS-2 bantalan hard rubber $10 \mathrm{~mm}$ mampu mereduksi momen negatif $L S-2$ tanpa karet sebesar 43,35 \%. Adapun momen tereduksi termasuk momen negatif. Untuk bantalan karet hard rubber $20 \mathrm{~mm}$ mereduksi momen sebesar $63,31 \%$ dan bantalan karet hard rubber $30 \mathrm{~mm}$ dapat mereduksi momen sebesar 76,17\%. Persentase reduksi momen ini dapat dilihat pada Tabel 5.

Tabel 5. Persentase momen pada $L S-2$ hard rubber

\begin{tabular}{|c|c|c|c|c|}
\hline Tebal & $\mathrm{M}_{0}$ & $\mathrm{M}_{1}$ & $\begin{array}{c}\text { Selisih } \\
\mathrm{M}_{0}-\mathrm{M}_{1}\end{array}$ & $\left(\frac{\mathrm{M}_{0}-\mathrm{M}_{1}}{\mathrm{M}_{0}}\right) \times 100$ \\
$(\mathrm{~mm})$ & kN.m & kN.m & kN.m & $\%$ \\
\hline 10 & -9.738 & -5.517 & -4.221 & 43.35 \\
\hline 20 & -9.738 & -3.573 & -6.165 & 63.31 \\
\hline 30 & -9.738 & -2.321 & -7.417 & 76.17 \\
\hline
\end{tabular}

Pada Tabel 5, $\mathrm{M}_{0}$ adalah momen yang terjadi akibat beban lalu lintas pada link slab tanpa bantalan karet sedangkan $\mathrm{M}_{1}$ adalah momen yang terjadi pada link slab setelah penambahan bantalan karet hard rubber pada zona transisi link slab dengan gelagar beton prategang. Kemudian dari hasil perhitungan persentase pada Tabel 5 diperoleh hubungan antara tebal bantalan karet hard rubber dengan perubahan momen yang terjadi seperti grafik pada Gambar 11.

Pada Gambar 11, dapat dilihat bahwa semakin tebal karet hard rubber semakin besar reduksi momen yang terjadi. Reduksi momen yang terkecil terjadi pada link slab bantalan karet hard rubber sebesar 43,35\% sedangkan reduksi momen yang terbesar adalah pada link slab bantalan karet hard rubber $30 \mathrm{~mm}$ sebesar 76,17\%.

\section{2) $L S$-2 bantalan soft rubber}

Pada $L S$-2 bantalan soft rubber $10 \mathrm{~mm}$, momen yang terjadi setelah pembebanan memiliki selisih sebesar 224,05 \%. Dengan menganggap terbaliknya momen negatif menjadi momen positif dengan selisih 200 $\%$ maka momen awal tidak mengalami 
perubahan besar momen jika dibandingkan dengan perubahan momen. Oleh karena perubahan momen yang terjadi sebesar $224,05 \%$ maka dengan mengurangi persentase ini dengan $200 \%$ diperoleh $24,05 \%$ sebagai tambahan momen yang terjadi. Angka 24,05\% ini juga dapat diperoleh dengan mengabaikan jenis momen negatif atau positif sehingga selisih dapat diperoleh dan didapatkan presentase tambahan $24,05 \%$. Perhitungan persentasi ini dapat di lihat pada Tabel 6 .

Tabel 6. Persentase perubahan momen pada LS 2-soft rubber

\begin{tabular}{|c|c|c|c|c|}
\hline Tebal & $\mathrm{M}_{0}$ & $\mathrm{M}_{1}$ & $\begin{array}{c}\text { Selisih } \\
\mathrm{M}_{0}-\mathrm{M}_{1}\end{array}$ & $\left(\frac{\mathrm{M}_{0}-\mathrm{M}_{1}}{\mathrm{M}_{0}}\right) \times 100$ \\
$(\mathrm{~mm})$ & kN.m & kN.m & kN.m & $\%$ \\
\hline 10 & -9.738 & 12.08 & -21.818 & 224.05 \\
\hline 20 & -9.738 & 11.9 & -21.638 & 222.20 \\
\hline 30 & -9.738 & 11.17 & -20.908 & 214.71 \\
\hline
\end{tabular}

Pada Tabel 6 di atas, $\mathrm{M}_{0}$ adalah momen yang terjadi akibat beban lalu lintas pada link slab tanpa bantalan karet sedangkan $\mathrm{M}_{1}$ adalah momen yang terjadi pada link slab setelah penambahan bantalan karet soft rubber pada zona transisi link slab dengan gelagar beton prategang. Kemudian dari hasil perhitungan persentase pada Tabel 7 diperoleh hubungan antara tebal bantalan karet soft rubber dengan perubahan momen yang terjadi seperti grafik pada Gambar 12 .

Dari Gambar 12, dapat dilihat bahwa semakin tebal karet soft rubber semakin besar tambahan momen yang terjadi. Penambahan soft rubber pada LS-2 membuat momen awal (momen negatif) menjadi momen positif dan pada semua jenis tebal soft rubber momen yang terjadi $>200 \%$. Tambahan momen terbesar terjadi pada pada karet soft rubber tebal $10 \mathrm{~mm}$ sebesar 24,818 \% sedangkan pada soft rubber tebal $20 \mathrm{~mm}$ dan $30 \mathrm{~mm}$ terjadi tambahan momen sebesar $22,2 \%$ dan 14,71 $\%$. Dengan hasil ini dapat dikatakan bahwa semakin tipis tebal soft rubber semakin besar tambahan momen yang terjadi. c. Reduksi Momen pada $L S-3$

1) LS-3 bantalan hard rubber

Pada Link Slab beton $30 \mathrm{MPa}$ bantalan karet hard rubber $10 \mathrm{~mm}$ mampu mereduksi momen negatif Link Slab beton $35 \mathrm{MPa}$ tanpa karet sebesar 47,92\%. Adapun momen tereduksi termasuk momen negatif. Untuk bantalan karet hard rubber $20 \mathrm{~mm}$ mereduksi momen sebesar $69,76 \%$ dan bantalan karet hard rubber $30 \mathrm{~mm}$ dapat mereduksi momen sebesar $83,42 \%$. Persentase reduksi momen ini dapat dilihat pada Tabel 7.

Tabel 7. Persentase momen pada LS 3-hard rubber

\begin{tabular}{|c|c|c|c|c|}
\hline Tebal & $\mathrm{M}_{0}$ & $\mathrm{M}_{1}$ & $\begin{array}{c}\text { Selisih } \\
\mathrm{M}_{0}-\mathrm{M}_{1}\end{array}$ & $\left(\frac{\mathrm{M}_{0}-\mathrm{M}_{1}}{\mathrm{M}_{0}}\right) \times 100$ \\
$(\mathrm{~mm})$ & kN.m & kN.m & kN.m & $\%$ \\
\hline 10 & -8.687 & -4.524 & -4.163 & 47.92 \\
\hline 20 & -8.687 & -2.627 & -6.06 & 69.76 \\
\hline 30 & -8.687 & -1.44 & -7.247 & 83.42 \\
\hline
\end{tabular}

Pada Tabel 7 di atas, $\mathrm{M}_{0}$ adalah momen yang terjadi akibat beban lalu lintas pada link slab tanpa bantalan karet sedangkan $\mathrm{M}_{1}$ adalah momen yang terjadi pada link slab setelah penambahan bantalan karet hard rubber pada zona transisi link slab dengan gelagar beton prategang. Kemudian dari hasil perhitungan persentase pada Tabel 7 diperoleh hubungan antara tebal bantalan karet hard rubber dengan perubahan momen yang terjadi seperti grafik pada Gambar 11 Dari Gambar 11, dapat dilihat bahwa semakin tebal karet hard rubber pada $L S-3$ semakin besar reduksi momen yang terjadi. Reduksi momen yang terkecil terjadi pada link slab bantalan hard rubber tebal $10 \mathrm{~mm}$ sebesar $47,92 \%$ sedangkan reduksi momen yang terbesar adalah pada link slab bantalan karet hard rubber $30 \mathrm{~mm}$ sebesar $83,42 \%$.

\section{2) $L S-3$ bantalan soft rubber}

Pada LS-3 bantalan soft rubber $10 \mathrm{~mm}$, momen yang terjadi setelah pembebanan memiliki selisih sebesar $244,58 \%$ terhadap 
$L S$-3 tanpa bantalan Selisih ini membuat posisi $L S-3$ bantalan soft rubber berada pada area momen positif dan $L S-3$ tanpa bantalan berada pada area momen negatif. Perhitungan persentasi ini dapat di lihat pada Tabel 8.

Dari Tabel $8, \mathrm{M}_{0}$ adalah momen yang terjadi akibat beban lalu lintas pada link slab tanpa bantalan karet sedangkan $\mathrm{M}_{1}$ adalah momen yang terjadi pada link slab setelah penambahan bantalan karet soft rubber pada zona transisi link slab dengan gelagar beton prategang. Kemudian dari hasil perhitungan persentase pada Tabel 8 diperoleh hubungan antara tebal bantalan karet soft rubber dengan perubahan momen yang terjadi seperti grafik pada Gambar 12 .

Tabel 8. Persentase perubahan momen pada $L S-3$

\begin{tabular}{|c|c|c|c|c|}
\hline Tebal & $\mathrm{M}_{0}$ & $\mathrm{M}_{1}$ & $\begin{array}{c}\text { Selisih } \\
\mathrm{M}_{0}-\mathrm{M}_{1}\end{array}$ & $\left(\frac{\mathrm{M}_{0}-\mathrm{M}_{1}}{\mathrm{M}_{0}}\right) \times 100$ \\
$(\mathrm{~mm})$ & $\mathrm{kN} . \mathrm{m}$ & $\mathrm{kN} . \mathrm{m}$ & $\mathrm{kN} . \mathrm{m}$ & $\%$ \\
\hline 10 & -8.687 & 12.56 & -21.247 & 244.58 \\
\hline 20 & -8.687 & 12.35 & -21.037 & 242.17 \\
\hline 30 & -8.687 & 11.56 & -20.247 & 233.07 \\
\hline
\end{tabular}

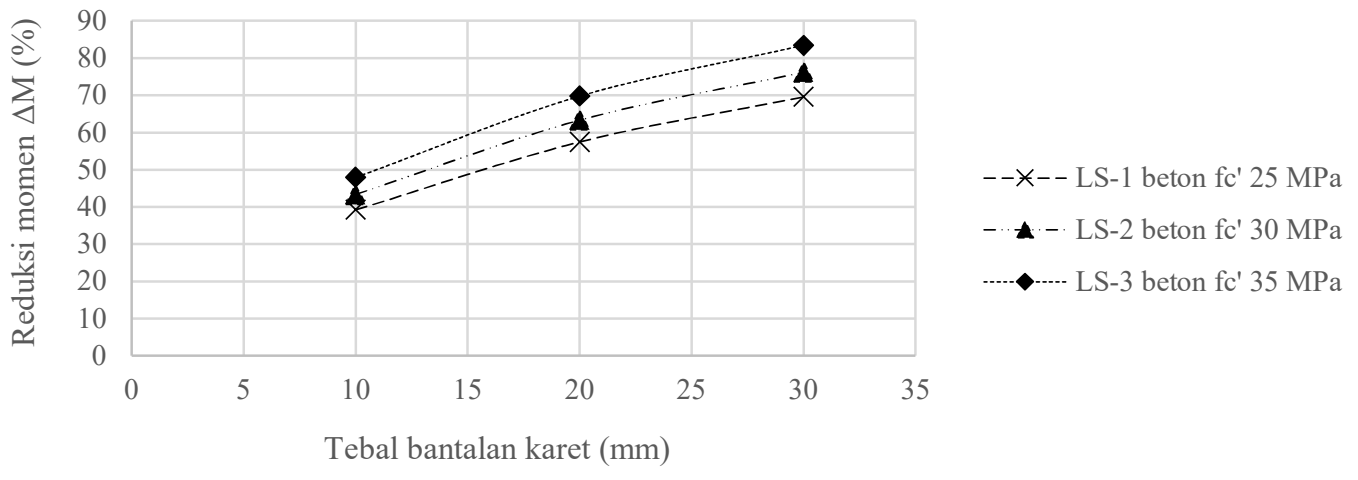

Gambar 11. Hubungan antara tebal karet hard rubber dengan perubahan momen yang terjadi pada $L S-1, L S-2$, dan $L S-3$

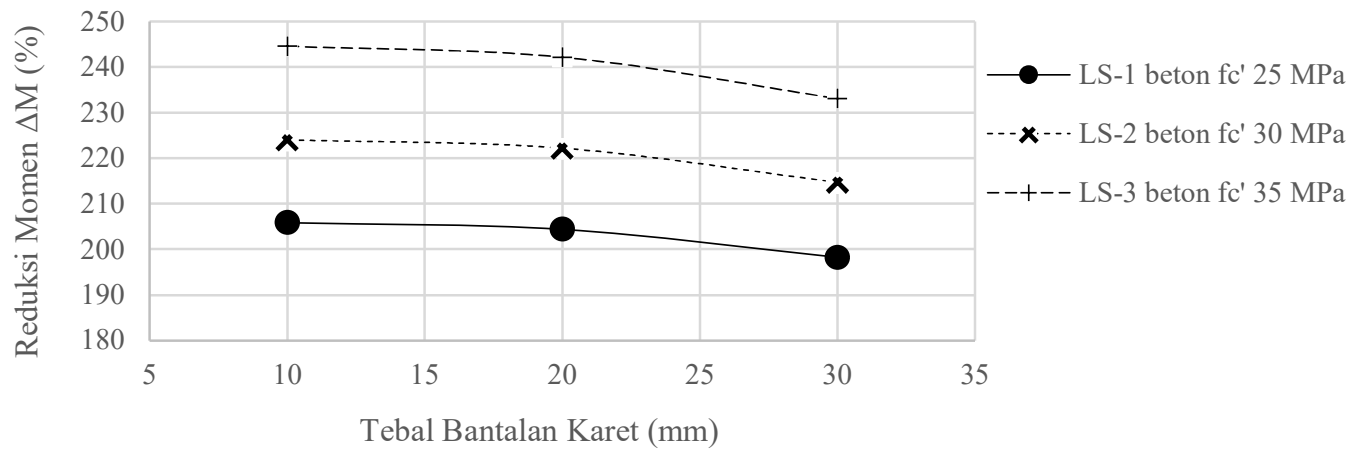

Gambar 12. Hubungan antara tebal karet soft rubber dengan perubahan momen yang terjadi pada Link Slab beton $L S-1, L S-2$, dan $L S-3$

Dari Gambar 12, dapat dilihat bahwa semakin tipis karet soft rubber semakin besar tambahan momen yang terjadi. Penambahan soft rubber pada LS-3 membuat momen awal (momen negatif) menjadi momen positif dan pada semua jenis tebal soft rubber momen yang terjadi $>200 \%$. Tambahan momen terbesar terjadi pada pada karet soft rubber tebal $10 \mathrm{~mm}$ sebesar 44,58 \% sedangkan pada soft 
rubber tebal $20 \mathrm{~mm}$ dan $30 \mathrm{~mm}$ terjadi tambahan momen sebesar 42,17 \% dan $33,07 \%$. Dengan hasil ini dapat dikatakan Desain link slab beton tanpa bantalan karet dalam penelitian ini terjadi aksi komposit antara permukaan bawah link slab dengan permukaan atas top flange gelagar di antara jarak sta (arah z) 28,3 m - 30,6 m dan 30,8 $\mathrm{m}-33,1 \mathrm{~m}$. Daerah 30,6 m - 30,8 m adalah area gap antar gelagar.

Gambar 13 (a) adalah detail penempatan hard rubber pada permukaan bawah link slab dengan jarak sta 28,3 $\mathrm{m}-30,6 \mathrm{~m}$ dan 30,8 m. sedangkan Gambar 13 (b) adalah mekanisme bantalan hard rubber yang bersifat sebagai spring dan bagian link slab jarak 30,6 $\mathrm{m}$ dan 30,8 $\mathrm{m}$ dianggap berlaku sebagai perletakan sendi-sendi. Perilaku ini juga berlaku pada link slab tanpa bantalan karet.

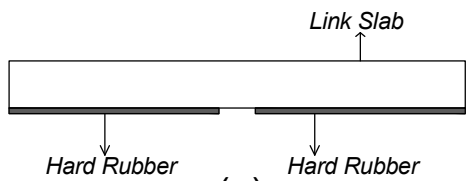

(a)

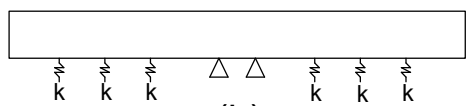

(b)

Gambar 13. Analisis link slab beton dengan bantalan hard rubber setelah mekanisme pembebanan seperti pada Gambar 8 .

Kondisi ini mengakibatkan momen yang terjadi pada area sepanjang gap adalah momen positif. Penambahan bantalan hard rubber mengakibatkan momen positif ini tereduksi dan semakin tebal bantalan hard rubber semakin besar reduksi momen yang diperoleh.

Jika dibandingkan dengan penelitian oleh Qian dkk (2009) link slab tanpa dan dengan bantalan karet tidak berlaku seperti engsel antara dua bentang yang berdekatan.

Gambar 14 (a) adalah detail penempatan soft rubber pada permukaan bawah link bahwa semakin tipis tebal soft rubber semakin besar tambahan momen yang terjadi.

slab dengan jarak sta $28,3 \mathrm{~m}-30,6 \mathrm{~m}$ dan 30,8 m. sedangkan Gambar 14 (b) adalah mekanisme bantalan soft rubber yang bersifat sebagai spring dan bagian link slab pada sta $28,3 \mathrm{~m}$ dan $31,1 \mathrm{~m}$ dianggap berlaku sebagai perletakan sendi-sendi. Kondisi ini mengakibat momen tengah bentang link slab (area link slab di atas gap) berada pada momen negatif yang jika ditinjau besarannya lebih besar dibandingkan dengan link slab tanpa dan dengan bantalan karet.
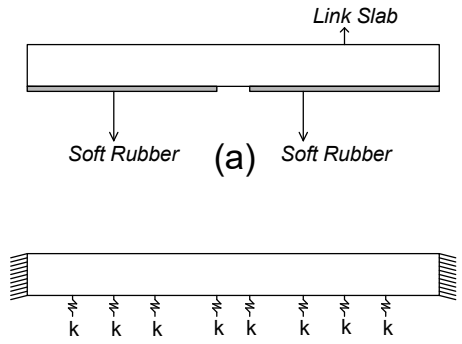

(b)

Gambar 14. Analisis link slab beton dengan bantalan soft rubber setelah mekanisme pembebanan seperti pada Gambar 8 .

Dari hasil pemodelan link slab dengan bantalan soft rubber jika dibandingkan dengan penelitian oleh Qian dkk (2009) link slab berlaku seperti engsel antara dua bentang yang berdekatan.

Dari penelitian ini penggunaan bantalan hard rubber dapat mereduksi momen yang terjadi akibat pembebanan. Dengan demikian bantalan hard rubber dianggap memberikan manfaat secara tinjauan numerik dengan metode elemen hingga.

Untuk tinjauan penggunaan hard rubber lebih jauh disarankan untuk dilakukan pengujian laboratorium agar dapat dijadikan pembanding sehingga faktor keamanan penggunaan bantalan karet dan 
dijadikan pertimbangan design link slab pada sistem jembatan semi-menerus.

\section{KESIMPULAN}

Dari hasil pemodelan bahwa penambahan bantalan hard rubber pada variasi tebal dapat mereduksi besar momen negatif dibandingkan dengan tanpa bantalan karet. Hal ini ditunjukkan oleh persentase reduksi momen sebesar 39,20 \% untuk tebal bantalan karet $10 \mathrm{~mm}, 57,47 \%$ untuk tebal tebal bantalan $20 \mathrm{~mm}$, dan $69,59 \%$ pada link slab beton fc' $25 \mathrm{MPa}$. Untuk link slab beton fc' $30 \mathrm{MPa}$ bantalan karet hard rubber berturut-turut untuk tebal bantalan $10 \mathrm{~mm}, 20 \mathrm{~mm}$, dan $30 \mathrm{~mm}$ terjadi persentase reduksi sebesar 43,35\%, 63,31 $\%$ dan 76,17\%. Untuk link slab beton fc' 35 MPa bantalan karet hard rubber terjadi reduksi sebesar $47,92 \%, 69,76 \%$ dan 83,42 $\%$ untuk tebal karet $10 \mathrm{~mm}, 20 \mathrm{~mm}$, dan 30 $\mathrm{mm}$.

Pada bantalan karet soft rubber untuk tebal antara $10 \mathrm{~mm}$ sampai $30 \mathrm{~mm}$ terjadi perilaku semakin tipis bantalan karet semakin besar tambahan momen yang terjadi. Hal ini ditunjukan oleh persentase momen yang terjadi sebesar 205, $87 \%, 204$, $4 \%$ dan 198, $26 \%$ untuk tebal bantalan karet soft rubber $10 \mathrm{~mm}, 20 \mathrm{~mm}$ dan 30 mm pada link slab beton fc' $25 \mathrm{MPa}$. Pada link slab beton fc' $30 \mathrm{MPa}$ terjadi selisih momen sebesar 224,05\%, 222,2 \% dan $214,71 \%$ untuk tebal bantalan karet soft rubber $10 \mathrm{~mm}, 20 \mathrm{~mm}$ dan $30 \mathrm{~mm}$. Sedangkan untuk link slab beton $35 \mathrm{MPa}$ terjadi selisih momen sebesar 244,58\%, $242,17 \%$ dan $233,07 \%$. Selisih yang besar ini diakibatkan pengaruh perpindahan area momen dari momen positif (kondisi awal) menjadi momen negative setelah penambahan bantalan soft rubber.

\section{DAFTAR PUSTAKA}

Badan Standarisasi Nasional, (2016). "SNI 1725: 2016 Pembebanan Untuk
Jembatan". Jakarta: Badan Standarisasi Nasional.

Badan Standarisasi (2013). "SNI 2847:2013 Persyaratan Beton Struktural untuk Bangunan Gedung”. Jakarta: Badan Standarisasi Nasional

Cotell, C. M., Sprague, J. A., Smidt, Jr. F. A., (1994) "ASM HANDBOOK VOLUME 5 Surface Engineering". The ASM International Handbook Committee.

Hong, Yu., (2014). "Analysis and Design of Link Slabs in Jointless Bridges with Fibre-Reinforced Concrete". Waterloo-Ontario-Canada: University of Waterloo.

Karnoop, D.C., Margolis, D.L., Rosenberg, R.C. (2012). "System Dynamics: Modeling, Simulation, and Control of Mechanics Systems, Fifth Edition". John Wiley \& Sons, Inc.: Canada.

Li, V.C., Fisher G., Kim, Y., Lepech, M., Qian, S., Weimann, M. dan Wang,S. (2003). "Durable Link Slabs for Jointless Bridge Decks Based on Strain-Hardening Cementitious Composites". University of Michigan.

Mothe, Ram Naren., (2006). "Partial continuity in prestressed concrete girder bridges with jointless decks". India : The Department of Civil and Environmental Engineering B.E., Osmania University.

Qian, S., D. Michael, Y. Lepech, Y. Kim, and V.C Li. (2009). "ACI Structural Journal. Introduction of Transition Zone Design for Bridge Deck Link Slabs Using Ductile Concrete". 1, V. 106, No. 1, January-February 2009: 96-105.

Seymour and Raymond, B. 1990. "Engineering Polymer 
Sourcebook”. McGraw-Hill : United States.

Sugihardjo, H and Supani. (2009). "Introduction of Repairing and Joining Methods for SimplySupported Prestressed Bridges Using Link Slab". 1st International on rehabilitation and Maintenance in Civil Engineering (ICRMCE), Solo: 66-73.

Sugihardjo, H., Piscesa, B., dan Irawan, F. (2010). "Studi Penggunaan Link Slab Pada Jembatan Komposit". Surabaya: Institut Teknologi Surabaya.

Victorianto, E. (2018). “Optimasi Jembatan Integral Beton Pracetak Prategang I-Girder Untuk Jalan Raya". Universitas Gadjah Mada, Yogyakarta. 